\title{
Assessment of Arsenic Accumulation by Different Varieties of Rice (Oryza sativa L.) Irrigated with Arsenic-contaminated Groundwater in West Bengal (India)
}

\author{
Piyal Bhattacharya \\ Department of Environmental Science, Kanchrapara College, West Bengal-743 145, India \\ Email: piyal_green@yahoo.co.in
}

\begin{abstract}
A study was conducted to investigate the bioaccumulation of arsenic by twelve different high yielding, hybrid and local rice varieties, cultivated in the Nadia district, West Bengal (India). The results showed that rice plant accumulated arsenic from irrigation water but, the magnitude of accumulation was found to vary with the rice varieties. Some of the examined rice varieties (like IET 4094, IR 50, etc) were noticed to be higher accumulator of arsenic $(0.49 \pm 0.05-0.59 \pm 0.09 \mathrm{mg} / \mathrm{kg}$ dry weight) with respect to other varieties like Gaurishankar, Saltora, etc, which were detected to be comparatively low accumulator $(0.15 \pm 0.03-0.25 \pm 0.01 \mathrm{mg} / \mathrm{kg}$ dry weight $)$. While significant correlation $(\mathrm{r}=0.9-0.92)$ was observed between arsenic concentrations in rice husk and grain parts, an appreciable low efficiency $(\mathrm{TF}=0.08-0.19)$ was noticed in translocation of arsenic from root to straw.
\end{abstract}

Keywords: Arsenic; bioaccumulation; rice (Oryza sativa L.); west bengal.

\section{Introduction}

In West Bengal, India the presence of arsenic rich groundwater is a major public health concern. Nine out of the total twenty districts of West Bengal have groundwater arsenic contamination $[1,2]$. Arsenic accumulation in rice straw argued to cause threat to cattle population and, thus contaminated meat and milk may indirectly cause further threat to humans, especially children [3, 4]. Meharg and Rahman [5], and Islam et al. [6] had shown arsenic accumulation in rice grain up to $2 \mathrm{mg} / \mathrm{kg}$, which was much above the WHO recommended permissible limit in rice $(1 \mathrm{mg} / \mathrm{kg}$ dry weight). Williams et al. [7] reported that consumption of arsenic-contaminated rice on a regular basis with total arsenic content of $0.08 \mathrm{mg} / \mathrm{kg}$ would be as hazardous as drinking arsenic-contaminated water of concentration $0.01 \mathrm{mg} / \mathrm{l}$. In our previous study we had observed an appreciable high efficiency in translocation of arsenic from straw to grain (0.1-0.39) as compared to arsenic translocation from root to shoot $(0.04-0.11)$ in the rice plant [8]. In vivo studies conducted in the study area revealed that different rice varieties have different potential in accumulating arsenic from the same arsenic-contaminated irrigation water and paddy field soil $[8,9$, $10,11]$. The induction of arsenic in human food chain through consumption of rice thus imposes community health risk in arsenic affected areas of West Bengal $[12,13]$.

Different researchers have studied the effect of arsenic on diverse rice varieties cultivated around the world $[7,12,14]$. Green house pot experiments had also shown significant differences in the accumulations of arsenic in straw, husk and grain parts by different rice varieties with variation of arsenic concentration in pot soil $[9,12]$. Variation of arsenic accumulation in the Boro and Aman rice varieties was previously observed by Williams et al. [7], although the report was made on the basis of a food market survey. The objective of the present study was to determine the accumulation of arsenic in different fractions (root, straw, husk and grain) of the rice plant of various varieties (local, high yielding and hybrid) on seasonal basis, cultivated with arsenic-contaminated irrigation water in the Nadia district, West Bengal. This study would help to identify the rice varieties which are less susceptible to arsenic phytotoxicity, so that proper management strategy towards rice cultivation in the arseniccontaminated areas of West Bengal can be taken. 


\section{$2 \quad$ Materials and Methods}

\subsection{Study Area}

Three blocks of the Nadia district (Haringhata, Chakdaha and Ranaghat-I) are chosen as the present study area (Fig. 1) due to their high arsenic contamination level in groundwater [15]. Arsenic in groundwater of these areas is present in concentrations much above the WHO limit for drinking water $(0.01 \mathrm{mg} / \mathrm{l})[16]$ and the Food and Agricultural Organization (FAO) limit for irrigation water $(0.1 \mathrm{mg} / \mathrm{l})$ $[17]$.

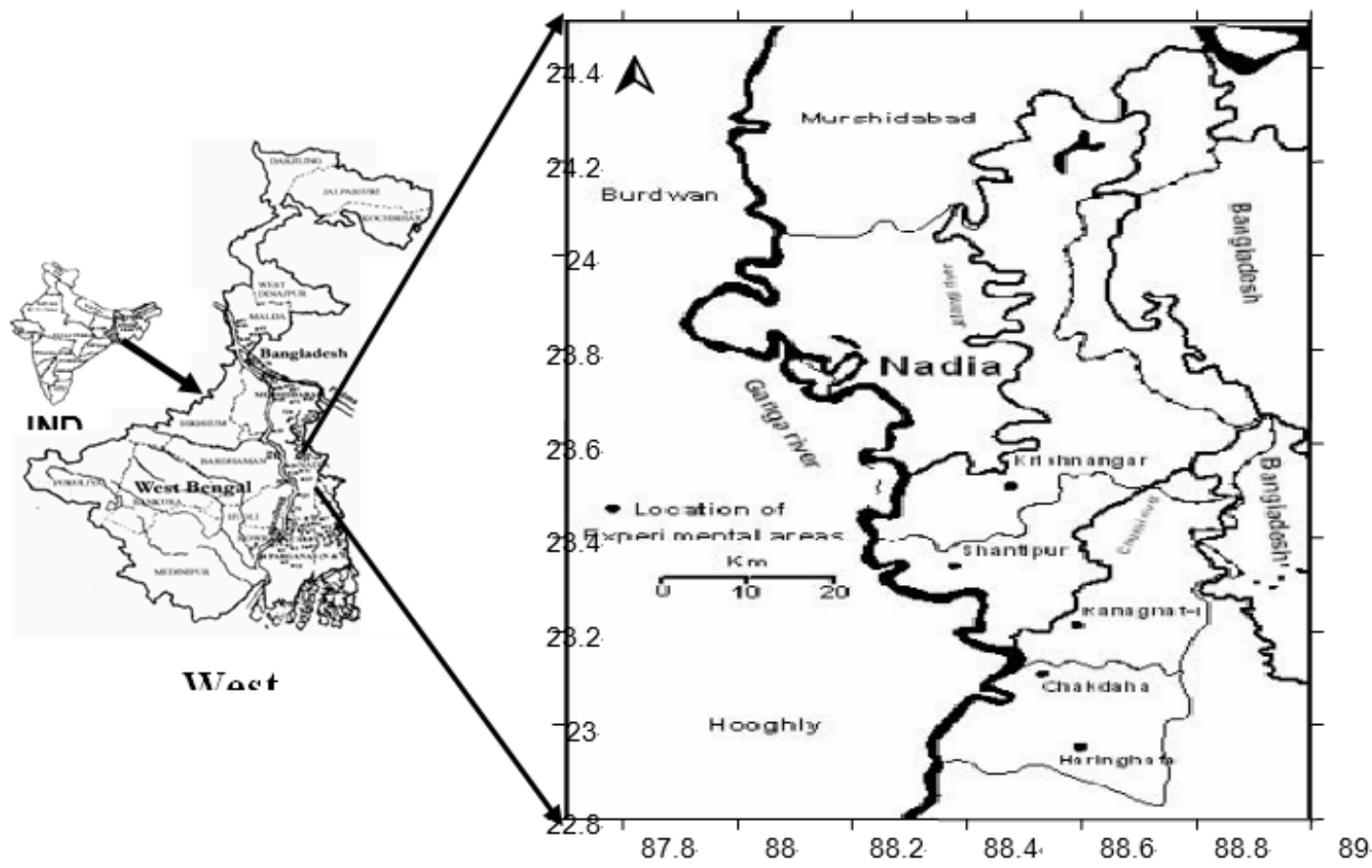

Figure 1. Site map of sampling locations: Haringhata, Chakdaha and Ranaghat-I blocks of Nadia district, West Bengal, India.

\subsection{Sample Collection}

Groundwater samples have been collected in polyethylene bottles, and preserved with concentrated $\mathrm{HNO}_{3}$ after collecting from shallow tube well pumps used for irrigation in the study area. Prior to sample collection, the pumps were kept running for about 10-15 min in order to get a uniform rate of discharging water. Soil samples were collected from $10-15 \mathrm{~cm}$ depth in a $2 \mathrm{~m}^{2}$ area by composite sampling technique from the paddy fields irrigated with arsenic-contaminated groundwater, and transferred to airtight polyethylene bags. Similarly, rice samples of twelve different varieties namely IET 4094, Gaurishankar, IR 50; Ratna, Red Minikit, White Minikit, Gangakaveri, Jaya, Lal Sanna, Saltora, Megi and Nayanmani were collected from selected plots $\left(2 \mathrm{~m}^{2}\right.$ areas) from the same site or at least as close as possible to the point where soil samples were collected. At each sampling site, three random subsamples of rice were collected and then those were aggregated into one sample for further treatment. 


\subsection{Sample Treatment}

The irrigation water samples were filtered using $0.45 \mu$ Millipore filter paper and $50 \mathrm{ml}$ filtered samples were kept in polyethylene bottles at $4^{\circ} \mathrm{C}$ for analysis. The soil samples were immediately sun dried and later dried in hot air oven at $60^{\circ} \mathrm{C}$ for $72 \mathrm{~h}$. The dried soil samples were then grinded by cautiously disaggregating in a mortar and screened through $2 \mathrm{~mm}$ pore sized sieve to get a homogenized representative powder sample. Finally airtight polyethylene bags were used to store the samples at room temperature. For rice samples at first arsenic free water and later deionized water were used to thoroughly wash the samples for the removal of soil and other contaminants. The samples were then dried in hot air oven at $60^{\circ} \mathrm{C}$ for $72 \mathrm{~h}$ and were stored in airtight polyethylene bags at room temperature with proper labeling. Proper care was taken at each step to minimize any contamination. The heating block digestion procedure [9] was applied to digest the soil samples, root, straw, husk and grain of the collected rice samples. Prior to sample digestion all glass apparatus were washed with $2 \% \mathrm{HNO}_{3}$ followed by rinsing with deionized water and drying.

\subsection{Sample Analysis}

Total arsenic of the digested samples and irrigation water samples were analyzed by the flow injection hydride generation atomic absorption spectrophotometer (FI-HG-AAS, Perkin Elmer AAnalyst 400) using external calibration [18]. For each sample three replicates were taken, and the mean value and standard deviations were obtained on the basis of calculation of those three replicates. To ensure continued accuracy Standard Reference Materials (SRM) from National Institute of Standards and Technology (NIST), USA were estimated in the same procedure at the start, during and at the end of the measurements. The observed arsenic concentrations $(\mathrm{mg} / \mathrm{kg}$ dry weight) of SRM were as follows: San Joaquin soil (SRM 2709A) 17.3 \pm 0.5 (certified value $17.7 \pm 0.8$ ) and Rice Flour (SRM 1568A) 0.28 \pm 0.07 (certified value $0.29 \pm 0.03$ ). The certified and the observed values were thus in good agreement.

\subsection{Statistical Analysis}

SPSS, version 16.0 for windows (SPSS Inc., Chicago, USA) was used to estimate the Pearson's correlation among arsenic concentrations in different parts (root, straw, husk and grain) of the rice plant.

\subsection{Translocation Factor (TF)}

Translocation factor is defined as the ratio of a metal's concentration $(\mathrm{mg} / \mathrm{kg})$ in plant's aerial parts $($ CAerial) to the concentration $(\mathrm{mg} / \mathrm{kg})$ of the metal in plant's root $(\mathrm{CRoot}), \mathrm{TF}=($ CAerial $/ \mathrm{CRoot})$.

\section{$3 \quad$ Results and Discussion}

In the study area Boro rice is cultivated during winter (November-March) and in pre-monsoon season (March-June). The irrigation in these periods is mostly done by groundwater as a result of low or no rainfall. Aman rice is monsoon rain fed and grown between July and December; groundwater irrigation is generally not required for its cultivation as there is plenty availability of monsoon water. The physicochemical soil characteristics of the collected paddy field samples are shown in Table 1 . The overall arsenic contents in the collected irrigation water, soil and in the different parts of rice plant varieties cultivated in the three blocks of Nadia district are presented in Table 2. The results showed that in the Boro rice season the irrigation water had an average arsenic concentration of $0.45 \pm 0.09$ $\mathrm{mg} / \mathrm{l}$, whereas the same in the Aman rice season set down to $0.39 \pm 0.13 \mathrm{mg} / \mathrm{l}$. The paddy soil was observed to getting contaminated from the irrigation water and the average arsenic concentrations (mg/kg dry weight) in the agricultural soil were found to be $6.4 \pm 1.1$ and $5.1 \pm 1.3$ for the Boro and Aman rice seasons, respectively. The arsenic content of soil of the study area was evaluated to be within the European Community recommended acceptable limit for arsenic $(20 \mathrm{mg} / \mathrm{kg})$ in agricultural soil [9]. The arsenic concentration in the irrigation water of the study area was found to be much higher than the WHO recommended permissible limit of $0.01 \mathrm{mg} / \mathrm{l}$ for drinking water [16] and FAO recommended permissible limit for irrigation water $(0.1 \mathrm{mg} / \mathrm{l})[17]$. 
Table 1. Soil characteristics of the arsenic-contaminated rice fields of the Nadia district.

\begin{tabular}{l|l}
\hline Soil parameters & Values \\
\hline Clay (\%) & $71-81$ \\
\hline Sand (\%) & $5.7-6.8$ \\
\hline Silt (\%) & $12-24$ \\
\hline Texture & Clay loam \\
\hline $\mathrm{pH}$ & $7.7 \pm 0.30$ \\
\hline Organic carbon $(\%)$ & $0.72 \pm 0.09$ \\
\hline
\end{tabular}

Table 2. Concentrations of arsenic in the irrigation water, soil and in tissues of the rice plant cultivated in the three blocks of the Nadia district.

\begin{tabular}{|c|c|c|c|c|c|c|c|}
\hline \multirow{3}{*}{$\begin{array}{l}\text { Rice } \\
\text { type }\end{array}$} & \multirow[t]{3}{*}{ Rice varieties } & \multicolumn{6}{|c|}{ Concentrations of arsenic (mean $\pm \mathrm{SD}$ ) } \\
\hline & & \multirow{2}{*}{$\begin{array}{l}(\mathrm{mg} / \mathrm{l}) \\
\text { Irrigation water }\end{array}$} & \multicolumn{5}{|c|}{$(\mathrm{mg} / \mathrm{kg})$} \\
\hline & & & Soil & Rice root & Rice straw & Rice husk & Rice grain \\
\hline \multirow[t]{7}{*}{ Boro } & IET 4094 & \multirow[t]{7}{*}{$0.45 \pm 0.09$} & \multirow[t]{7}{*}{$6.4 \pm 1.1$} & $10 \pm 1.3$ & $1.2 \pm 0.27$ & $0.94 \pm 0.25$ & $0.55 \pm 0.09$ \\
\hline & Gaurishankar & & & $19 \pm 4.1$ & $1.4 \pm 0.07$ & $0.72 \pm 0.06$ & $0.15 \pm 0.03$ \\
\hline & IR 50 & & & $19 \pm 2.3$ & $2.2 \pm 0.19$ & $0.92 \pm 0.17$ & $0.53 \pm 0.07$ \\
\hline & White Minikit & & & $14 \pm 3.6$ & $2.1 \pm 0.19$ & $0.69 \pm 0.17$ & $0.32 \pm 0.01$ \\
\hline & Ratna & & & $16 \pm 2.4$ & $1.6 \pm 0.24$ & $0.87 \pm 0.13$ & $0.44 \pm 0.09$ \\
\hline & Gangakaveri & & & $20 \pm 4.9$ & $1.6 \pm 0.32$ & $0.91 \pm 0.15$ & $0.49 \pm 0.05$ \\
\hline & Jaya & & & $19 \pm 3.8$ & $2 \pm 0.11$ & $0.93 \pm 0.08$ & $0.54 \pm 0.07$ \\
\hline \multirow[t]{5}{*}{ Aman } & Lal Sanna & \multirow[t]{5}{*}{$0.39 \pm 0.13$} & \multirow[t]{5}{*}{$5.1 \pm 1.3$} & $9.9 \pm 2.4$ & $1.4 \pm 0.27$ & $0.68 \pm 0.14$ & $0.39 \pm 0.07$ \\
\hline & Saltora & & & $12 \pm 2$ & $1.2 \pm 0.15$ & $0.56 \pm 0.09$ & $0.22 \pm 0.03$ \\
\hline & Megi & & & $8.7 \pm 1.6$ & $1.6 \pm 0.14$ & $0.66 \pm 0.25$ & $0.25 \pm 0.01$ \\
\hline & Red Minikit & & & $12 \pm 2.8$ & $1.4 \pm 0.16$ & $0.76 \pm 0.02$ & $0.53 \pm 0.03$ \\
\hline & Nayanmani & & & $10 \pm 3.2$ & $1.7 \pm 0.19$ & $0.91 \pm 0.13$ & $0.59 \pm 0.09$ \\
\hline
\end{tabular}

The arsenic accumulation ( $\mathrm{mg} / \mathrm{kg}$ dry weight) in various parts of the Boro rice plants was found to have the following ranges, in root: $10-20$, in straw: $1.2-2.2$, in husk: $0.69-0.94$ and in grain: $0.15-0.55$. The accumulation in the Aman rice was detected to be in the following ranges, in root: 8.7-12, in straw: 1.2-1.7, in husk: $0.56-0.91$ and in grain: $0.22-0.59$. The arsenic contents in the different rice plant parts of the studied Boro and Aman rice samples are shown in Fig. 2 and 3, respectively. On an average the accumulation of arsenic in various parts of the rice plant was found to be more during the winter season (Boro rice) than that in the monsoon season (Aman rice). This is clearly linked with the extensive use of arsenic-contaminated groundwater for irrigation during the winter. This finding is concurrent with the observations made earlier by Abedin et al. [3] and Meharg and Rahman [5].

Higher accumulation of arsenic (0.49 $\pm 0.05-0.59 \pm 0.09 \mathrm{mg} / \mathrm{kg}$ dry weight) was found in the IET 4094, IR 50, Nayanmani, Jaya, Gangakaveri and Red Minikit rice varieties, as compared to the Gaurishankar, Saltora and Megi rice varieties with much lower efficiency in arsenic accumulation $(0.15 \pm$ 0.03-0.25 $\pm 0.01 \mathrm{mg} / \mathrm{kg}$ dry weight). IET 4094, IR 50, Nayanmani, Jaya, Gangakaveri and Red Minikit are all high yielding varieties (HYV) of rice. Low accumulator Gaurishankar is a hybrid rice variety, whereas Saltora and Megi are two local varieties. Medium accumulation of arsenic $(0.32 \pm 0.01-0.44 \pm$ 0.09) was observed in the White Minikit, Ratna and Lal Sanna rice varieties. While Lal Sanna is a local rice variety, the other two are HYVs. The results thus reveal significant variation in arsenic uptake and accumulation by the studied local, high yielding and hybrid rice varieties. Similar observations were previously reported by Alam et al. [14], Williams et al. [7] and Rahman et al. [9]. In our previous study we had observed relatively higher translocation (0.19-0.39) of arsenic in the Red Minikit variety as compared to the translocation $(0.1-0.16)$ by a local rice variety, Megi [8]. Rahman et al. [9] reported that arsenic translocation from root to shoot (straw) and husk was much higher in a hybrid rice variety as compared to those by studied four other non-hybrid rice varieties. 


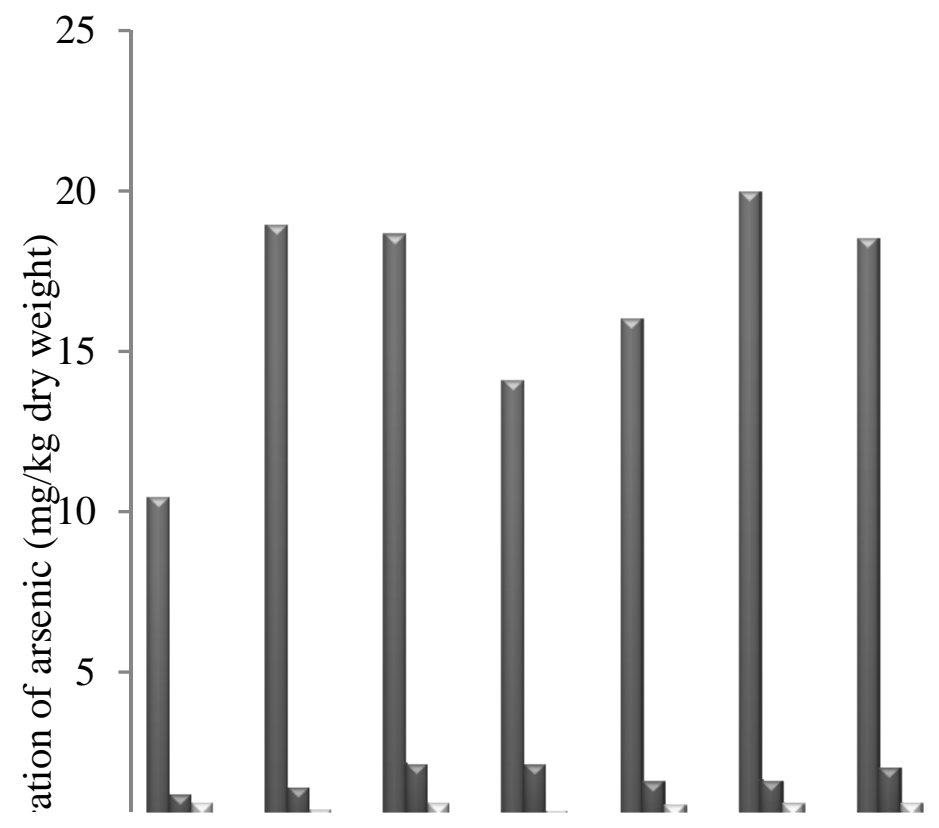

Figure 2. Graphical representation of the concentrations of arsenic in different parts of the rice plant (Oryza sativa L.) of the studied Boro varieties.

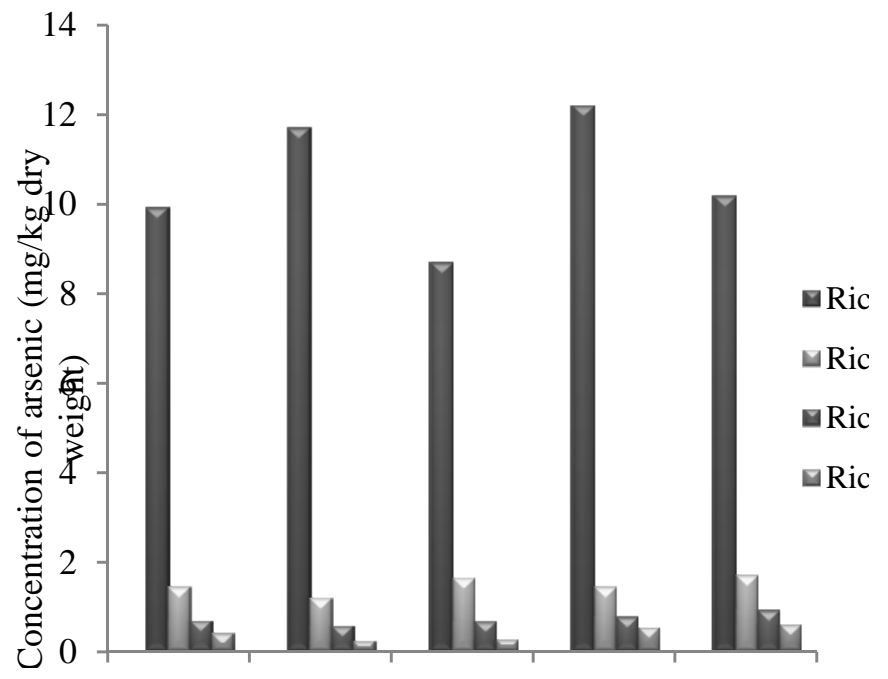

Figure 3. Graphical representation of the concentrations of arsenic in different parts of the rice plant (Oryza sativa L.) of the studied Aman varieties.

Present investigation results clearly showed that regardless of the rice variety arsenic accumulated $(\mathrm{mg} / \mathrm{kg}$ dry weight) mostly in root of the rice plant $(8.7 \pm 1.6-20 \pm 4.9)$, followed by the accumulation in straw $(1.2 \pm 0.15-2.2 \pm 0.19)$, husk $(0.56 \pm 0.09-0.94 \pm 0.25)$ and grain $(0.15 \pm 0.03-0.59 \pm 0.09)$ parts. This finding is in agreement with the findings by Liu et al. [19], Rahman et al. [9] and Bhattacharya et al. [8]. According to Liu et al. [20] the iron oxides or iron plaques formed around root of the rice plant are responsible for the arsenic binding in root. The resultant is the reduction of translocation of arsenic from root to straw, husk, and grain portions of the rice plant. Arsenic accumulation in rice straw has serious consequences to livestock population of the study area and, thus 
indirectly to human health through the intake of arsenic-contaminated meat and milk. The accumulation of arsenic in grain of all the studied rice samples remained within the WHO recommended permissible limit in rice $(1 \mathrm{mg} / \mathrm{kg}$ dry weight).

The correlation coefficients (r) among arsenic concentrations in different parts (root, straw, husk and grain) of rice plant for both the Boro and Aman rice samples are shown in Table 3. It is interesting to note the fact that in both the rice types there is significant correlation between the arsenic concentrations in rice husk and grain parts $(r=0.9-0.92)$, whereas strong negative correlation was observed among the arsenic concentrations in rice root, husk and grain parts. The TF values of arsenic from root of the rice plant to higher plant parts were determined to understand the observed negative correlations among the arsenic concentrations in rice root, husk and grain parts (Table 4). The results indicated an appreciable low efficiency $(\mathrm{TF}=0.08-0.19)$ in translocation of arsenic from root to shoot whereas $\mathrm{TF}$ values were found to be much higher from shoot to grain $(\mathrm{TF}=0.11-0.46)$ for almost all the analyzed rice varieties. The lower TF values for translocation of arsenic from root to shoot revealed the strong capability of root tissues to hold the arsenic, which was related with the presence of iron plaques [20]. Other than the White Minikit variety, translocation of arsenic from straw to grain $(\mathrm{TF}=$ 0.25-0.46) by all other HYVs was evaluated to be much higher than those by the studied local and hybrid rice varieties.

Table 3. Correlation coefficients ( $\mathrm{r}$ ) among arsenic concentrations in different parts of the rice plant of different varieties cultivated in the three blocks of Nadia district.

\begin{tabular}{l|l|l|l|l|l}
\hline Rice type & & Root & Straw & Husk & Grain \\
\hline \multirow{4}{*}{ Boro } & Root & 1 & & & \\
\cline { 2 - 6 } & Straw & -0.32 & 1 & & \\
\cline { 2 - 6 } & Husk & -0.17 & 0.03 & 1 & \\
\cline { 2 - 6 } & Grain & -0.06 & 0.2 & $0.9^{* *}$ & 1 \\
\hline \multirow{4}{*}{ Aman } & Root & 1 & & & \\
\cline { 2 - 6 } & Straw & -0.37 & 1 & & \\
\cline { 2 - 6 } & Husk & -0.24 & 0.26 & 1 & 1 \\
\hline & Grain & -0.07 & 0.37 & $0.92^{* *}$ & 1 \\
\hline
\end{tabular}

** Correlation is significant at the 0.01 level (1-tailed).

Table 4. Translocation factor (TF) of arsenic from root to straw and from straw to grain in the different rice varieties cultivated in the three blocks of Nadia district.

\begin{tabular}{l|l|l}
\hline Rice varieties & TF from root to straw & TF from straw to grain \\
\hline IET 4094 & 0.12 & 0.46 \\
\hline Gaurishankar & 0.08 & 0.11 \\
\hline IR 50 & 0.12 & 0.25 \\
\hline White Minikit & 0.15 & 0.15 \\
\hline Ratna & 0.10 & 0.28 \\
\hline Gangakaveri & 0.08 & 0.30 \\
\hline Jaya & 0.11 & 0.27 \\
\hline Lal Sanna & 0.14 & 0.27 \\
\hline Saltora & 0.10 & 0.19 \\
\hline Megi & 0.19 & 0.15 \\
\hline Red Minikit & 0.12 & 0.37 \\
\hline Nayanmani & 0.17 & 0.35 \\
\hline
\end{tabular}

\section{Conclusions}

Ganga-Meghna-Bramhaputra basin is designated as one of the major arsenic-contaminated hotspots in the world. The increasing cases of chronic arsenicosis in this region have resulted in intensive research 
on arsenic enrichment in groundwater as well as in foodstuffs, as there are potential health risks associated with exposure to arsenic from both the sources. Rice cultivation requires immense amount of water; long term irrigation with groundwater rich in arsenic may lead to increase of arsenic level in paddy soil and finally result into arsenic accumulation in rice plants. Hence, contamination of arsenic in irrigation water and in soil was examined to study the accumulation of arsenic as well as its partition in different parts (root, straw, husk, and grain) of rice plant from arsenic-effected Nadia district of West Bengal. Arsenic accumulation in the rice plant was found to differ with the analyzed rice varieties. Almost all the examined HYVs were detected to accumulate medium to high amount of arsenic as compared to accumulation by the studied hybrid and local rice varieties. Thus, the farmers are encouraged to cultivate those rice varieties which are found to be less susceptible to arsenic phytotoxicity in the study area. Rice is the main staple food of rural people of the study area, thus the arsenic contamination in rice straw and grain fractions beyond the WHO recommended permissible value could have major impacts on human health. Periodical monitoring on the status of arsenic accumulation in rice plant of the study area is recommended as the severity of arsenic toxicity is increasing day by day. A large section of people have been already diagnosed to be suffering from arsenicosis and other types of arsenic-induced allied diseases via food chain. Intake of rice straw by cattle population of the area could possibly contribute to enhanced arsenic in their milk or meat. It would unfold a new pathway of arsenic entrance to human food chain.

Acknowledgement. The author is thankful to the Department of Environment, Government of West Bengal (India) for funding this investigation as well as for the award of Junior Research Fellowship.

\section{References}

1. R. T. Nickson, J. M. McArthur, P. Ravenscroft, W. G. Burgess, and K. M. Ahmed, "Mechanism of arsenic release to groundwater, Bangladesh and West Bengal", Appl Geochem, vol. 15, pp. 403-413, 2000.

2. A. C. Samal, S. Kar, P. Bhattacharya, and S. C. Santra, "Human exposure to arsenic through foodstuffs cultivated using arsenic contaminated groundwater in areas West Bengal, India", J Environ Sci Health, Part A, vol. 46, no. 11, pp. 1259-1265, 2011.

3. M. J. Abedin, M. S. Cresser, A. A. Meharg, J. Feldmann, and J. Cotter-Howells, "Arsenic accumulation and metabolism in rice (Oryza sativa L.)", Environ Sci Technol, vol. 36, no. 5, pp. 962-968, 2002.

4. M. A. Rahman, H. Hasegawa, M. M. Rahman, M. A. M. Miah, and A. Tasmin, "Arsenic accumulation in rice (Oryza sativa L.): human exposure through food chain", Ecotoxicol Environ Saf, vol. 69, pp. 317-324, 2008.

5. A. A. Meharg, and M. M. Rahman, "Arsenic contamination of Bangladesh paddy field soil: implication for rice contribution to arsenic consumption", Environ Sci Technol, vol. 37, pp. 229-234, 2003.

6. M. R. Islam, M. Jahiruddin, G. K. M. M. Rahman, M. A. M. Miah, A. T. M. Farid, G. M. Panaullah et al., "Assessment of arsenic in the water-soil-plant systems in Gangetic flood plains of Bangladesh", Asian J Plant Sci, vol. 3, pp. 489-493, 2004.

7. P. N. Williams, M. R. Islam, A. Raab, S. A. Hossain, and A. A. Meharg, "Increase in rice grain arsenic for regions of Bangladesh irrigating paddies with elevated arsenic in ground water", Environ Sci Technol, vol. 40, pp. 4903-4908, 2006.

8. P. Bhattacharya, A. C. Samal, J. Majumdar, and S. C. Santra, "Accumulation of arsenic and its distribution in rice plant (Oryza sativa L.) in Gangetic West Bengal, India" Paddy Water Environ, vol. 8, no. 1, pp. 63-70, 2010.

9. M. A. Rahman, H. Hasegawa, M. M. Rahman, M. A. Rahman, and M. A. M. Miah, "Accumulation of arsenic in tissues of rice plant (Oryza sativa L.) and its distribution in fractions of rice grain", Chemosphere, vol. 69, pp. 942-948, 2007.

10.P. Bhattacharya, A. C. Samal, J. Majumdar, and S. C. Santra, "Uptake of arsenic in rice plant varieties cultivated with arsenic rich groundwater", EnvironmentAsia, vol. 3, no. 2, pp. 34-37, 2010.

11.P. Bhattacharya, A. C. Samal, J. Majumdar, and S. C. Santra, "Arsenic contamination in rice, wheat, pulses and vegetables: a study in an arsenic affected area of West Bengal, India", Water Air Soil Pollut, vol. 213, pp. 3-13, 2010. 
12.P. Bhattacharya, A. C. Samal, J. Majumdar, S. Banerjee, and S. C. Santra, "In vitro assessment on the impact of soil arsenic in the eight rice varieties of West Bengal, India", J Hazard Mater, vol. 262, pp. 1091-1097, 2013.

13.S. C. Santra, A. C. Samal, P. Bhattacharya, S. Banerjee, A. Biswas, and J. Majumdar, "Arsenic in foodchain and community health risk: a study in Gangetic West Bengal", Procedia Environ Sci, vol. 18, pp. 2-13, 2013.

14.M. Z. Alam, and M. M. Rahman, "Accumulation of arsenic in rice plant from arsenic contaminated irrigation water and effect on nutrient content", in F. Ahmed, M. A. Ali, and Z. Adeel (ed.) BUET-UNU International symposium of fate of arsenic in the environment, Dhaka, Bangladesh. Conference paper, 2003, pp. 131-135.

15.P. Bhattacharya, A. C. Samal, J. Majumdar, and S. C. Santra, "Transfer of arsenic from groundwater and paddy soil to rice plant (Oryza sativa L.): a micro level study in West Bengal, India", World J Agric Sci, vol. 5, no. 4, pp. 425-431, 2009.

16.World Health Organization, "Arsenic and arsenic compounds, environmental health criteria", 2nd edn, WHO, Geneva, 2001, pp. 224.

17.Food and Agricultural Organization, "Water quality guidelines for maximum crop production", FAO/UN 1985, Available: www.fao.org/docrep/T0551E.2006/9/13.

18.F. P. Welsch, J. G. Crock, and R. Sanzolone, "Trace elements determination of arsenic and selenium using continuous-flow hydride generation atomic absorption spectrophotometry (HG-AAS)", in B. F. Arbogast (ed.) Quality assurance manual for the branch of geochemistry, 1990, pp. 38-45.

19.W. J. Liu, Y. G. Zhu, Y. Hu, P. N. Williams, A. G. Gault, A. A. Meharg, et al., "Arsenic sequestration in iron plaque, its accumulation and speciation in mature rice plants (Oryza Sativa L.)", Environ Sci Technol, vol. 40, pp. 5730-5736, 2006.

20.W. J. Liu, Y. G. Zhu, S. A. Smith, and S. E. Smith, "Do iron plaque and genotypes affect arsenate uptake and translocation by rice seedlings (Oryza sativa L.) grown in solution culture?", J Exp Bot, vol. 55, no. 403, pp. 1707-1713, 2004. 